\title{
Pengembangan Aplikasi Pelaporan Kuliah Kerja Terpadu Universitas Sam Ratulangi
}

\author{
Hermawan Lalompoh $^{1)}$, Yaulie Deo Y. Rindengan ${ }^{2)}$, Arie S. M. Lumenta ${ }^{3)}$ \\ Program Studi Teknik Informatika, Fakultas Teknik, Universitas Sam Ratulangi \\ hermawanlalompoh28@gmail.com,rindengan@unsrat.ac.id,al@unsrat.ac.id
}

\begin{abstract}
Kuliah Kerja Terpadu (KKT) adalah bentuk kegiatan pengabdian kepada masyarakat oleh mahasiswa dengan pendekatan lintas keilmuan dan sektoral pada waktu dan daerah tertentu. Direktorat Jendral Pendidikan Tinggi di Indonesia telah mewajibkan setiap perguruan untuk melaksanakan KKT sebagai kegiatan intrakurikuler yang memadukan tri dharma perguruan tinggi yaitu : pendidikan, penelitian, dan pengabdian kepada masyarakat. Diakhir kegiatan mahasiswa diwajibkan membuat laporan yang isinya adalah kegiatan, informasi atau gambaran serta program dari sejak perencanaan, pelaksanaan serta hasil yang dicapai. Penelitian ini bertujuan membuat sistem yang dapat memudahkan dalam melaporkan kegiatan KKT. Penelitian ini juga menggunakan metode RAD (Rapid Application Development). RAD adalah metode pengembangan aplikasi yang relefan dalam pembuatan sistem ini. Dari penelitian tersebut maka akan menghasilkan aplikasi web yang dapat diakses dengan mudah.
\end{abstract}

Kata kunci-KKT, Pelaporan, RAD, Web

Abstract - Integrated Working Lecture (KKT) is a form of community service activities by students with a cross-scientific and Sectoral approach at a particular time and area. The Directorate General of Higher Education in Indonesia has obliged every university to implement the KKT as an Intrakurikuler activity that combines tri dharma of higher education is research, and community service. At the end of the activity the student is required to make a report whose contents are activities, information or description and program from the moment of planner, the implementation and the result achieved. This study aims to create a system that can facilitate in reporting KKT activities. This research also uses the RAD(Rapid Application Development) method, $R A D$ is a relevant application development method in making this system From the research it will produce web applications that can be accessed easy.

Keywords - KKT, RAD, Reporting, Web.

\section{Pendahuluan}

Kuliah Kerja Terpadu (KKT) adalah bentuk kegiatan pengabdian kepada masyarakat oleh mahasiswa dengan pendekatan lintas keilmuan dan sektoral pada waktu dan daerah tertentu. Direktorat Jendral Pendidikan Tinggi di Indonesia telah mewajibkan setiap perguruan untuk melaksanakan KKT sebagai kegiatan intrakurikuler yang memadukan tri dharma perguruan tinggi yaitu : pendidikan, penelitian, dan pengabdian kepada masyarakat. ${ }^{[7]}$. UNSRAT dalam hal ini LPPM sebagai penyelenggara telah memiliki banyak data- data laporan hasil KKN yang disimpan, datadata ini masih dalam bentuk laporan hasil print.

Perkembangan teknologi begitu sangat berdampak bagi kehidupan manusia, ada banyak pula keterbatasan manusia dapat terbantukan oleh perkembangan teknologi, baik di lingkungan medis, pemerintah, terlebih dalam lembaga pendidikan. Meskipun telah banyak aktivitas manusia telah dimudahkan oleh teknologi, masih ada juga masalah lain yang harus memanfaatkan teknologi untuk dapat memudahkan dan mengefisiensikan waktu kerja. Seperti pada masalah pada LPPM yang dimana telah banyak datadata laporan $\mathrm{KKN}$ yang terkumpul namun untuk mencari data-data itu perlu waktu yang lama, dalam hal ini peran teknologi akan sangat menolong yaitu dengan suatu sistem database yang akan nantinya dengan mudah menemukan data, tanpa harus mencari secara manual, juga mengatasi hilangnya data. Meninjau sangat diperlukan sistem seperti ini maka diajukan penelitian mengenai Aplikasi Pelaporan KKT Universitas Sam Ratulangi.

\section{A. . Pengertian Sistem Informasi}

Sistem adalah suatu jaringan kerja dari prosedur-prosedur yang saling berhubungan, berkumpul bersama-sama untuk melakukan suatu kegiatan atau untuk menyelesaikan suatu sasaran yang tertentu ${ }^{[1]}$. Secara etimologi, informasi merupakan kata atau istilah yang berasal dari informacion (Bahasa Perancis Kuno, tahun 1387). Sedangkan dalam bahasa Latin, informasi berasal dari kata Informationem yang mempunyai arti sebagai konsep ide atau garis besar. Dari kedua pengertian tersebut, dapat disimpulkan bahwa informasi merupakan suatu pengetahuan yang dapat dikomunikasikan dengan metode tertentu. Sistem informasi adalah kombinasi dari manusia, fasilitas atau alat teknologi, media, prosedur dan pengendalian yang ditujukan untuk mengatur jaringan komunikasi yang penting, proses transaksi tertentu dan rutin, membantu manajemen dan pemakai intern dan ekstern dan menyediakan dasar untuk pengambilan keputusan yang tepat.

\section{B. Pengertian World Wide Web}

WWW( World Wide Web) merupakan sebuah media informasi global yang menghubungkan antara pengguna ke server juga pengguna lain untuk menyajikan data, informasi, dokumen yang dapat digunakan bersama dengan format HTML. Dengan adanya $w w w$ di internet dapat memberikan kemudahan dan kecanggihan pengguna internet secara cepat. 


\section{HTML}

HTML sigkatan dari Hyper Text Markup Language yaitu bahasa pemfomatan teks untuk dokumen-dokumen pada jaringan komputer yang sering disebut sebagai world wide web, yang kemudian dapat diakses untuk menampilkan berbagai informasi di dalam sebuah penjelajahan web internet (Browser) ${ }^{[3]}$. HTML dapat juga digunakan sebagai link antara file-file dalam situs atau dalam komputer dengan menggunakan localhost,link yang menghubungkan antar situs dalam dunia internet.

\section{B. PHP}

PHP adalah bahasa pemrograman script server-side yang didesain untuk pengembangan web. PHP disebut bahasa pemrograman server side karena PHP diproses pada komputer server. Hal ini berbeda dibandingkan dengan bahasa pemrograman client-side seperti JavaScript yang diproses pada web browser (client). PHP dapat digunakan dengan gratis (free) dan bersifat Open Source. PHP dirilis dalam lisensi PHP License, sedikit berbeda dengan lisensi GNU General Public License (GPL) yang biasa digunakan untuk proyek Open Source.

\section{Data Base}

Database adalah sekumpulan tabel-tabel yang saling berelasi, relasi tersebut bisa ditunjukkan dengan kunci dari tiap tabel yang ada. Database menunjukkan satu kumpulan data yang dipakai dalam satu lingkup perusahaan atau instansi. Database dalam basis data bersifat integrated dan shared:

1) Terpadu (integrated), berkas-berkas data yang ada pada basis data saling terkait(terjadi dependensi data);

2) Berbagi data(shared), data yang sama dapat dipakai oleh sejumlah pengguna dalam waktu yang bersamaan. Sering dinamakan sebagai sistem multiuser.

Berikut ini jenis-jenis database :

1) Database Relationa (Relational Database) Merupakan jenis database yang terpopular. Database relational pengguna atau mengakses, update,dan mencari informasi berdasarkan hubungan data yang disimpan dalam tabel yang berbeda.Database relational juga dapat menjalankan query yang melibatkan beberap database.

2) Database Analitik (Analytical Processing)Database Analitik (atau OLAP-On Line Analytical Processing) merupakan database penyimpanan arsip atau data historis yang hanya dapat dibaca (read-only database), dan digunakan untuk analisis.

3) Database Operasional (disebut juga OLTP-On Line Transaction Processing), pada umumnya digunakan untuk mengelolah bit data yang lebih dinamis.

\section{D.XAMMP}

Xammp adalah perangkat lunak bantu yang dapat digunakan untuk melakukan pemrograman berbasis web tanpa harus melakukan instalasi paket perangkat lunak yang terpisah-pisah. ${ }^{[3]}$

Xammp berfungsi sebagai server yang berdiri sendiri (localhost), yang terdiri atas program Apache HTTP Server,
MySQL database,dan penerjemah bahasa yang ditulis dengan bahasa pemrograman PHP dan Perl. Program ini tersedia dalam GNU General Public Lisense dan bebas, web server yang mudah digunakan yang dapat melayani tampilan halaman web yang dinamis.

\section{E. $M y S Q L$}

MySQL adalah sebuah server database open source yang terkenal yang digunakan berbagai aplikasi terutama untuk server atau membuat web. MySQL berfungsi sebagai SQL(Structured Query Language) yang dimiliki sendiri dan sudah diperluas oleh MySQL, umumnya bersamaan dengan PHP untuk membuat aplikasi server yag dinamis dan powerfull.My SQL adalah sebuah implementasi dari sistem manajemen basis data relasional (RDBMS) yang didistribusikan secara gratis dibawah lisensi GPL(General Public Lisense).

\section{F. Model RAD}

RAD (Rapid Application Development) adalah proses model perangkat lunak inkremental yang menekankan siklus pengembangan yang singkat ${ }^{[2]}$. Model RAD merupakan adaptasi dari model waterfall, dimana perkembangan pesat dicapai dengan menggunakan pendekatan konstruksi berbasis komponen seperti pada gambar 1 .

\section{G.Kuliah Kerja Terpadu (KKT)}

Kuliah Kerja Terpadu (KKT) merupakan salah satu dari matakuliah wajib yang harus dikontrak mahasiswa. Sedianya KKT ini dikontrak pada semester menjelang akhir masa studi dengan memenuhi syarat tertentu. Pelaksanaan KKT adalah bentuk kegiatan pengapdian kepada masyarakat oleh mahasiswa dengan pendekatan lintas keilmuan dan sektoral pada waktu dan daerah tertentu. ${ }^{[5]}$

Sebagaimana yang telah diuraikan pada pendahuluan dimana direktorat jendral Pendidikan Tinggi di Indonesia telah mewajibkan setiap perguruan tinggi untuk melaksanakan KKT sebagai kegiatan intrakurikuler yang memadukan tri dharma perguruan tinggi yaitu : pendidikan,penelitian,dan pengapdian kepada masyarakat.

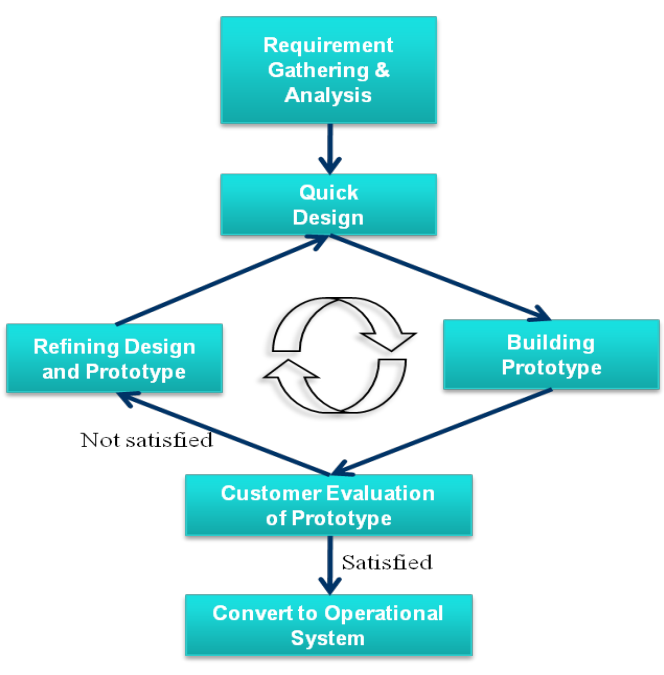

Gambar 1. Model UML 
Setiap mahasiswa yang telah mengikuti KKT diharapkan dewasa dalam pola pikir juga dalam menyelesaikan masalah yang akan nanti ditemui ketika sudah alumni atau bekerja. Selesai mengikuti KKT mahasiswa juga diharapkan memiliki sikap dan rasa cinta,kepedulian sosial, dan bertanggungjawab terhadap kemajuan masyarakan dengan memadukan ilmu yang telah dipelajari semasa menjalani studi.

KKT diselengarakan unsrat oleh LPPM (Lembaga Penelitian dan Pengabdian Masyarakat),Dengan Visi : LPPM Unsrat menjadi lembaga terkemuka dalam penelitian dan pengabdian kepada masyarakat berbasis keunggulan daerah dikawasan pasifik pada tahun 2020. LPPM unsrat memiliki beberapa misi,pada point 4 misi LPPM adalah mengembangkan pengabdian kepada masyarakat yang bersinergi, multidisiplin, dan bermitra melalui pelaksanaan KKT. . ${ }^{[4]}$

Dalam peningkatan dan pengembagannya LPPM dalam hal ini sebagai penyelengara KKT sangat berperan penting, terus mengupayakan cara efektif dalam penyelengaraan KKT, seperti yang sudah sementara berjalan dan digunakan yaitu pendaftaran dan pembagian posko secara online. KKT juga diadakan dilokasi yang berbeda pada tiap periodenya, sesuai dengan kesepakatan pemerintah yang berkaitan dan pihak LPPM.

\section{II.METODOLOGI PENELITIAN}

Lokasi dari Penelitian ini adalah Lembaga Penelitian dan Pengabdian Masyarakat (LPPM) Unsrat.

\section{A. Prosedur Penelitian}

Prosedur Penelitian merupakan bagian yang menguraikan tahapan proses alur kerja atau alur penelitian yang dapat dilihat pada gambar 2, dimana observasi, wawancara, dan studi literatur merupakan bagian dari pengumpulan data sedangkan rencana kebutuhan sampai pada tahap penyelesaian penelitian adalah bagian dari tahapan RAD.

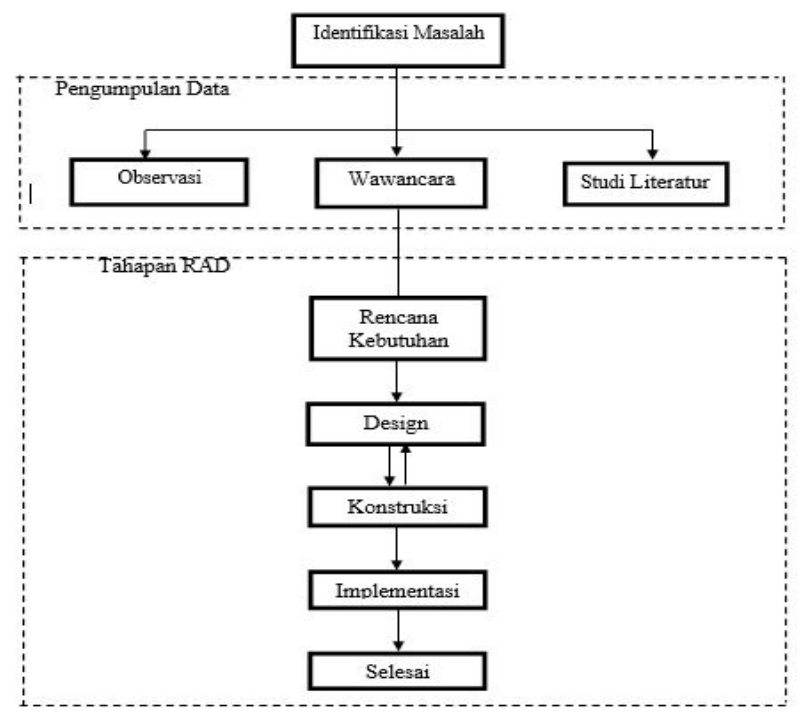

Gambar 2. Prosedur Penelitian

\section{B. Metode Pengembangan Sistem}

Pada pengembangan sistem ini penulis menggunakan metode $R A D$ untuk membangun sistem yang memberikan sebuah pendekatan yang dimulai pada analisa persyaratan modeling, desain modeling dan Konstruksi. ${ }^{[5]}$

\section{C.Analisa Persyaratan}

Pada tabel II menunjukkan spesifikasi pengguna dengan tiga pengguna yang mempunyai peran dan tanggung jawab yang berbeda-beda antara Admin, Dosen dan Mahasiswa.

\section{D.Analisa Modeling}

Tabel I menjelaskan daftar Actor dan tugas serta tanggung jawab pada sistem KKT.Dimana admin sebagai aktor adalah petugas lppm yang bertugas mengelolah data, sedangkan mahasiswa sebagai user hanya bisa melihat informasi dan mengupload data.

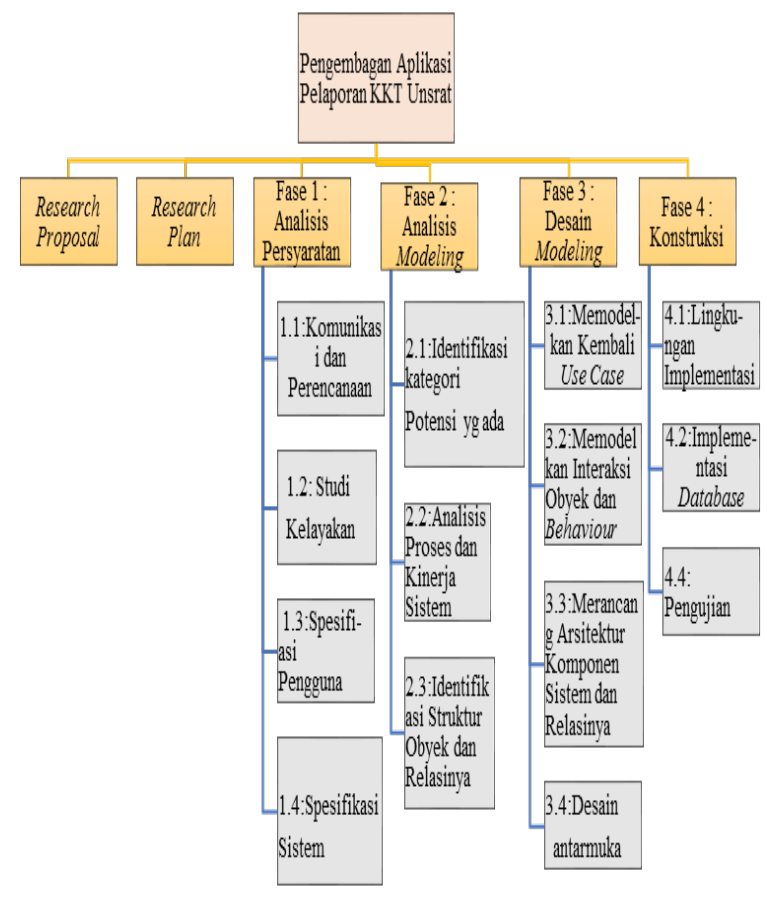

Gambar 3. Rencana Kerja Riset

TABEL I

SPESIFIKASI PENGGUNA

\begin{tabular}{|c|c|c|}
\hline Pengguna & Peran & Tanggung Jawab \\
\hline $\begin{array}{l}\text { Admin } \\
\text { (Petugas } \\
\text { LPPM) }\end{array}$ & Admin & $\begin{array}{l}\text { Aktor yang menggunakan } \\
\text { aplikasi untuk mengelolah } \\
\text { data aplikasi pelaporan } \\
\text { KKT }\end{array}$ \\
\hline $\begin{array}{l}\text { Mahasiswa } \\
\text { peserta } \\
\text { KKT, } \\
\text { dosen } \\
\text { pengawas, } \\
\text { petugas } \\
\text { LPPM }\end{array}$ & User & $\begin{array}{l}\text { Aktor yang menggunakan } \\
\text { Aplikasi Pelaporan KKT } \\
\text { dapat mengupload laporan, } \\
\text { dapat melihat hasil } \\
\text { laporan, menyimpan hasil } \\
\text { pelaporan, mengelolah dan } \\
\text { merekap laporan. }\end{array}$ \\
\hline
\end{tabular}


Hermawan Lalompoh - Pengembangan Aplikasi Kuliah Kerja Terpadu Universitas Sam Ratulangi

TABEL II IDENTIFIKASI PELAKU BISNIS

\begin{tabular}{ll}
\hline \hline \multicolumn{1}{c}{ Aktor } & Tugas dan Tanggung Jawab \\
\hline \hline Admin (Petugas & $\begin{array}{l}\text { Login admin, mengelolah data } \\
\text { pelaporan, dan sebagai sumber } \\
\text { informasi bagi user }\end{array}$ \\
User & $\begin{array}{l}\text { Melihat informasi pelaporan } \\
\text { Melihat informasi pelaporan, } \\
\text { (Maher }\end{array}$ \\
en, Petugas & melakukan rekapan pelaporan \\
LPPM & \\
\hline \hline
\end{tabular}

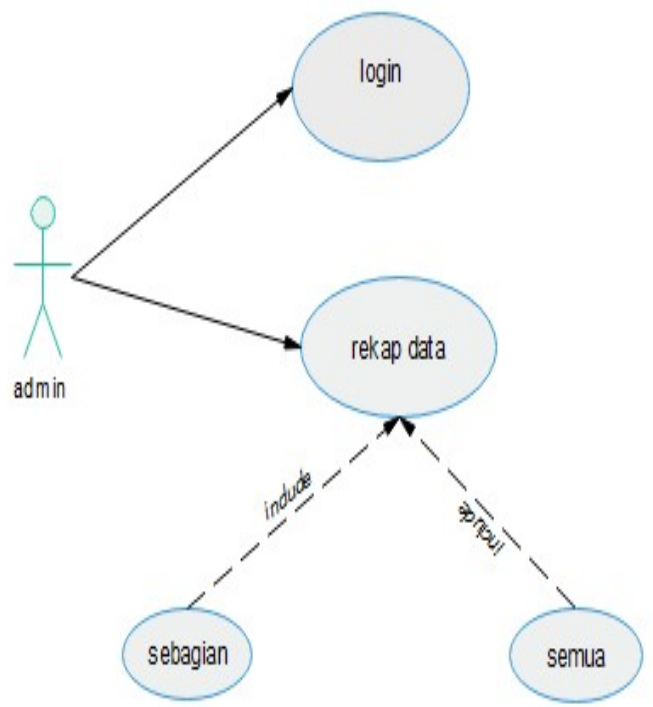

Gambar 4. Use Case Diagram Admin

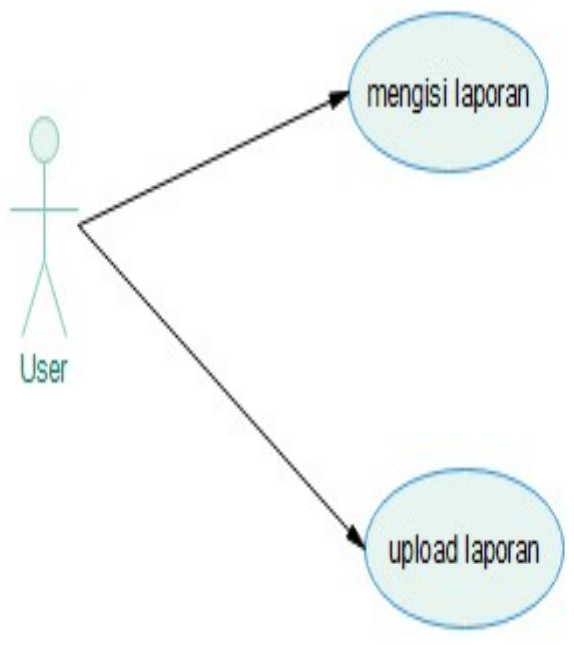

Gambar 5. Use Case Diagram User

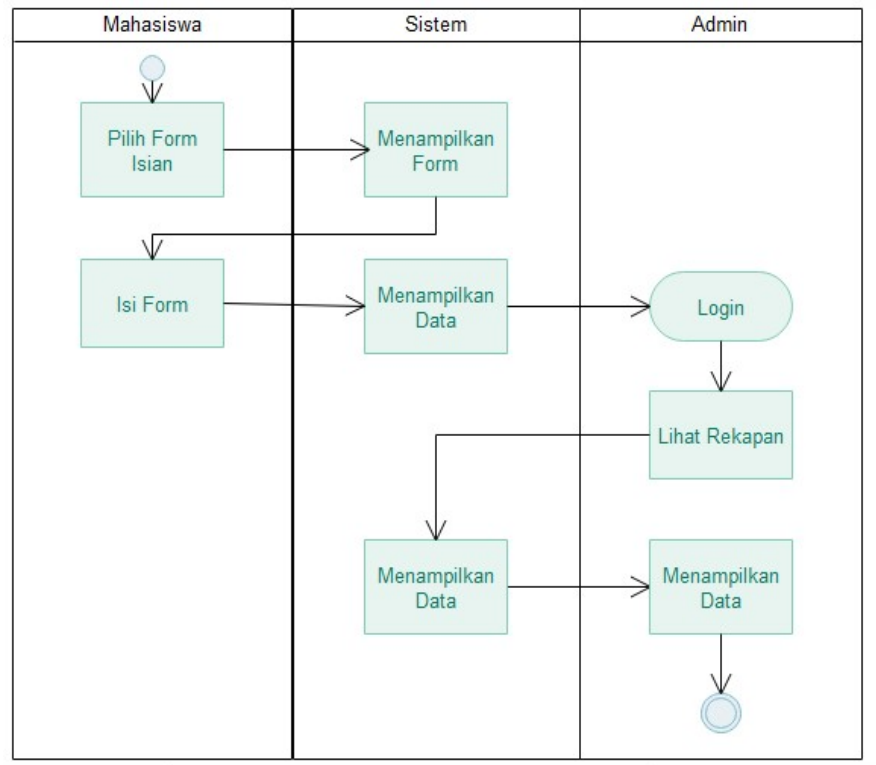

Gambar 6. Activity Diagram

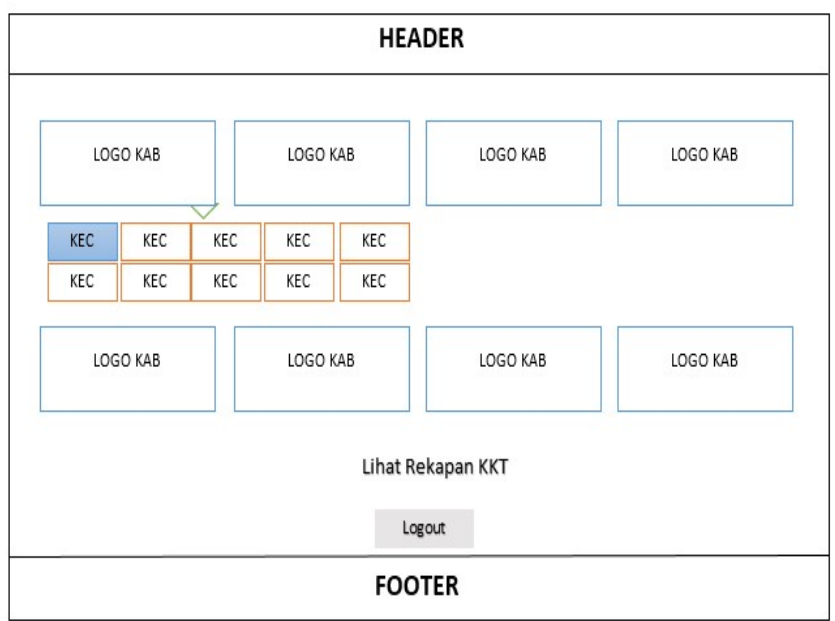

Gambar 7. Story Board Halaman Home

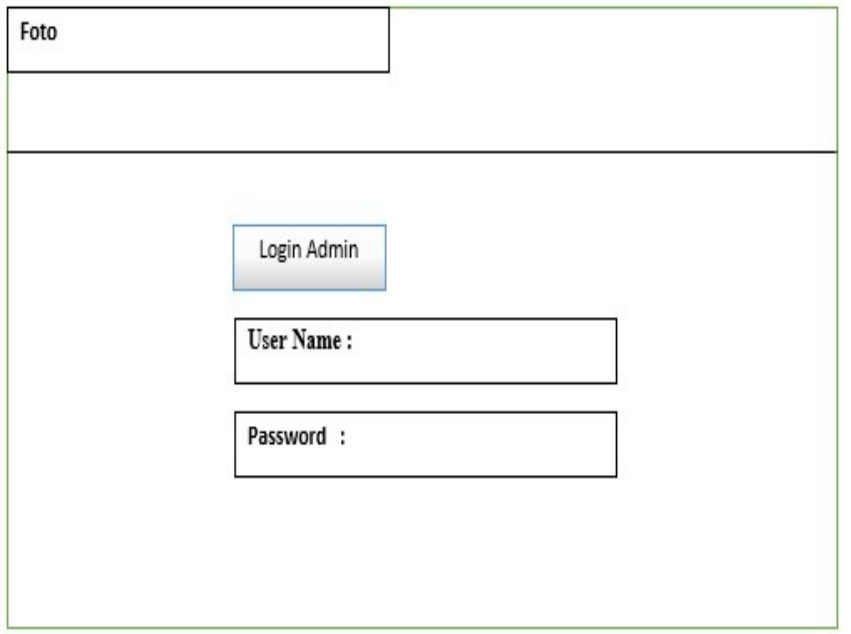

Gambar 8. Story Board Halaman Login 


\section{E. Tahapan Desain Modeling}

Pada Gambar 4 dan 5 menunjukkan Use Case Diagram. Use Case diagram dirancang untuk menunjukkan secara umum fungsi dan tanggung jawab masing-masing aktor sistem dalam pengembangan aplikasi pelaporan kuliah kerja terpadu.

Pada gambar 6 menunjukan activity diagram pengembangan aplikasi kuliah kerja terpadu. Activity Diagram dirancang untuk menunjukkan proses pemodelan sistem yang akan dirancang sesuai dengan keinginan peserta kuliah kerja terpadu. Activity diagram dapat digunakan untuk alur kerja model, use case individual, atau logika keputusan yang terkandung dalam metode individual. Activity diagram juga menyediakan pendekatan untuk proses pemodelan paralel.

\section{F. Rancangan Interface}

Pada gambar 7, dan gambar 8 diatas menunjukkan rancangan Interface yang akan dibuat. Berdasarkan spesifikasi desain yang diperoleh yaitu use case diagram dan use case description, terdapat beberapa fungsi yang akan dikembangkan dalam sistem.Story Board dibuat untuk menunjukkan bagaimana rancangan tampilan halaman sistem yang akan dikembangkan juga fungsi-fungsi dari setiap fitur sistem. Story Board yang dibuat yaitu login admin dan home user.

\section{G.Konstruksi}

Tahapan analisa konstruksi merupakan fase yang bertujuan untuk menampilkan platform dari perangkat keras dan perangkat lunak, serta batasan dalam implementasi, juga menguji permormen perangkat lunak yang dibangun, sehingga dapat diketahui apakah telah sesuai dengan analisa dan perancangan yang telah diidentifikasi sebelumnya. Dalam tahapan ini juga akan dilakukan proses kodefikasi yang dimana menerjemahkan hasil modeling kedalam coding atau kodefikasi program. Kode-kode sumber yang digunakan dalam tahapan ini antara lain kode sumber HTML dan CSS sebagai perancangan antarmuka atau interface sistem, serta code PHP sebagai bahasa pemrograman yang membentuk logika atau proses dari sistem.

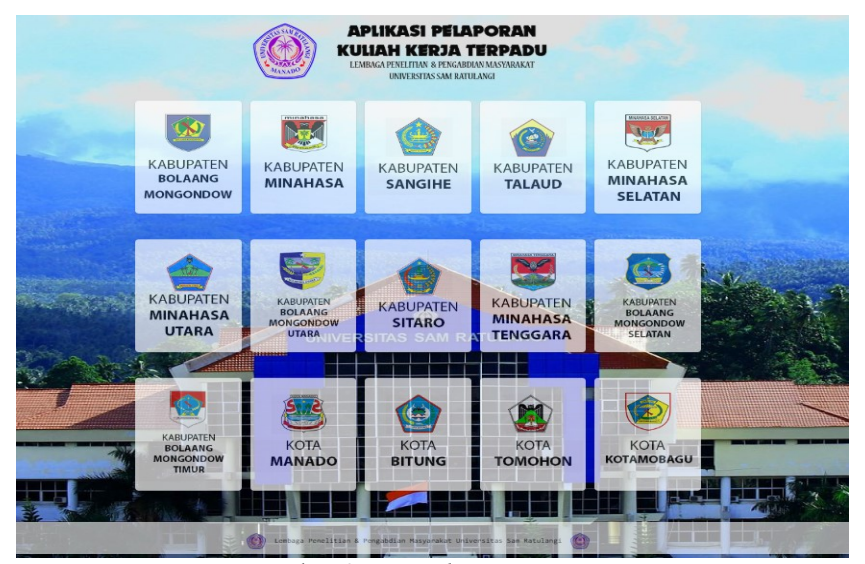

Gambar 9. Tampilan Menu Home

\section{HASIL DAN PEMBAHASAN}

\section{A. Implementasi Perencangan Sistem}

Implementasi merupakan tahap menerjemahkan layout yang sudah dibuat pada desain perancangan antar muka kedalam bentuk tampilan implementasi sistem secara utuh. Setelah melakukan semua tahapan sesuai dengan metode pengembangan sistem yaitu RAD (Rapid Application Development), pada tahap ini akan dijelaskan hasil dari penelitian yang dilakukan berdasarkan tujuan awal yaitu membuat suatu sistem.

1) Gambar 9 adalah tampilan menu home yang merupakan tampilan awal dimana menampilkan 15 kabupaten di sulawesi utara sebagai pilihan lokasi pelaksanaan Kuliah Kerja Terpadu Unseversitas Sam Ratulangi Manado.

2) Gambar 10 adalah tampilan menu home dimana menampilkan kecamatan yang akan dipilih oleh peserta kkt yang merupakan kecamatan tempat lokasi kkt. Tampilan kecamatan ini merupakan hasil setelah user mengakses kabupaten yang ada.

3) Gambar 11 adalah tampilan menu form pendaftan yang harus diisi oleh peserta kkt, dalam halaman ini peserta tidak bisa mengganti kabupaten dan kecamtan, karena sudah dipilih sebelumnya, juga dari sistem sudah membuat untuk tidak bisa diganti.

4) Gambar 12 adalah tampilan didalam form pelaporan yaitu saat peserta memilih desa lokasi penempatan peserta kkt sesuai pembagian dari petugas kkt. Peserta langsung memilih desa dan tidak perlu mengetikkannya karena sudah diinput dari sistem.
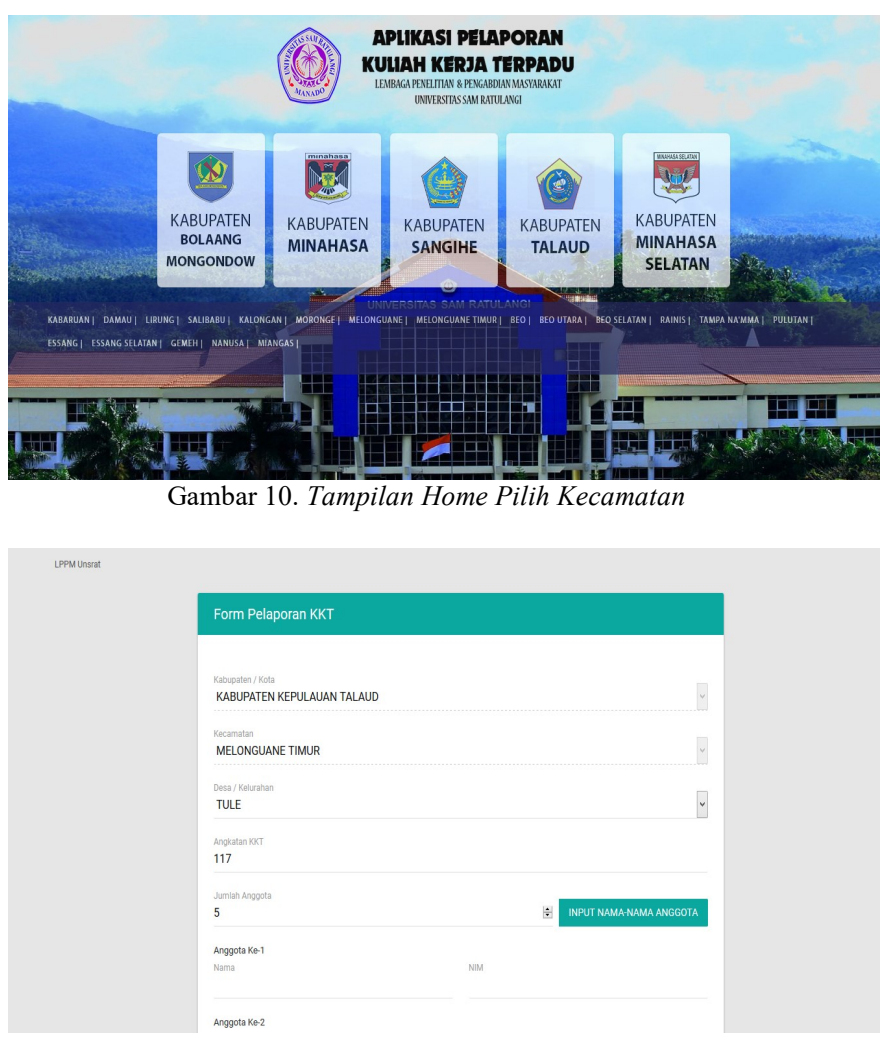

Gambar 11. Tampilan Form Pelaporan 
5) Gambar 13 adalah tampilan didalam form laporan yaitu saat peserta mengisi jumlah anggota, kemudian akan ditampilkan form nama,nim,dan fakultas. Untuk nama dan nim diketik sedangkan untuk fakultas hanya akan memilih karena sudah terinput didalam sistem.

6) Gambar 14 adalah tampilan didalam form laporan dimana memilih dosen pembimbing lapangan (DPL). Peseta juga tinggal memilih nama dosen karena sudah terinput didalam sistem.

7) Gambar 15 adalah tampilan didalam form laporan yaitu memilih document laporan hasil kkt, peseta diharuskan memasukkan laporan dalam bentuk pdf, word dan powerpoint. Untuk pdf diharuskan ada tanda tangan pembimbing.

\section{Form Pelaporan KKT}

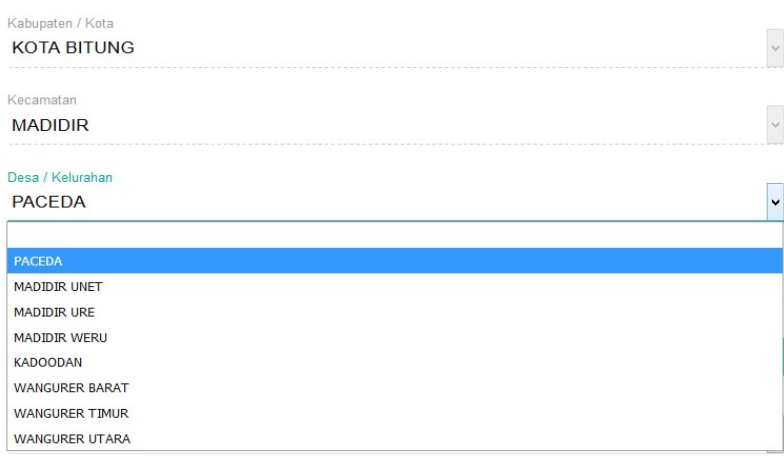

Gambar 12. Tampilan Memilih Desa

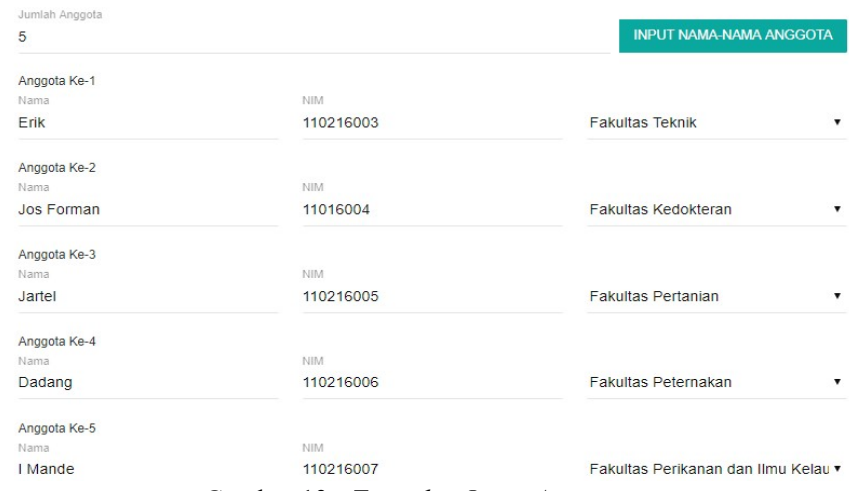

Gambar 13. Tampilan Input Anggota

Dosen Pembimbing Lapangan

Ellen Rangkere.SP.,M.S

Ellen Rangkere.SP,M.Si

Ir.Suzanne L.Undap.M.Si.Ph.D

Max K. Sondakh JR,SH,MH

Godlib Mamahit, SH,MH

Prof.Dr.Drs.Johnly A.Rorong,M.S

Dr.I.Ronny A.V.Tuturoong,M.Si

Dr.Djeine Imbang,M.Hum

Youlie Rindengan,ST,MSc,M

Arie S.M.Lumenta,ST,MT

Dr.dr.Josef S.B.Tuda,M.Kes,Sp Park.K

Ir.Ribka M.Kumaat,MS

Dra.Dolina L.Tampi,M.S

Ir.J.A.Malingkas,M.Si

Dr.dr.Altje Manmpiring,M. Kes

dr.Nancy Enka,M.Kes,AIFM

dr.Woodford B.S.Joseph,MS

Drs. Dantje Keles,M.Si

Dr.dr.Martha Kaseke,M.Kes

Stanley Karouw,ST.MTI

Gambar 14. Tampilan memilih DPL
8) Gambar 16 adalah tampilan memilih foto didalam form laporan untuk diupload. Peserta KKT diharuskan memilih 2 foto tematik, 2 foto kegiatan posko, 1 foto bersama dosen pembimbing lapangan, satu foto bersama pengawas lapangan.

9) Gambar 17 merupakan tampilan notifikasi ketika semua laporan berhasil diinput. Sebelum notifikasi ini didalam form terdapat persetujuan dimana menyatakan bahwa semua yang akan diinput adalah benar untuk disetujui oleh peserta. Dalam sistem juga mengharuskan peserta melengkapi semua form isian karena tidak bisa diinput apabila masih terdapat form yang belum diisi.

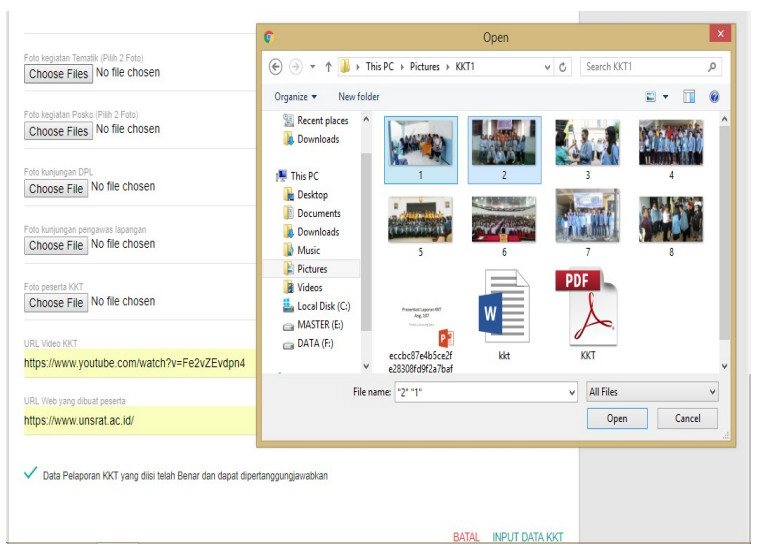

Gambar 15. Tampilan Memilih Document

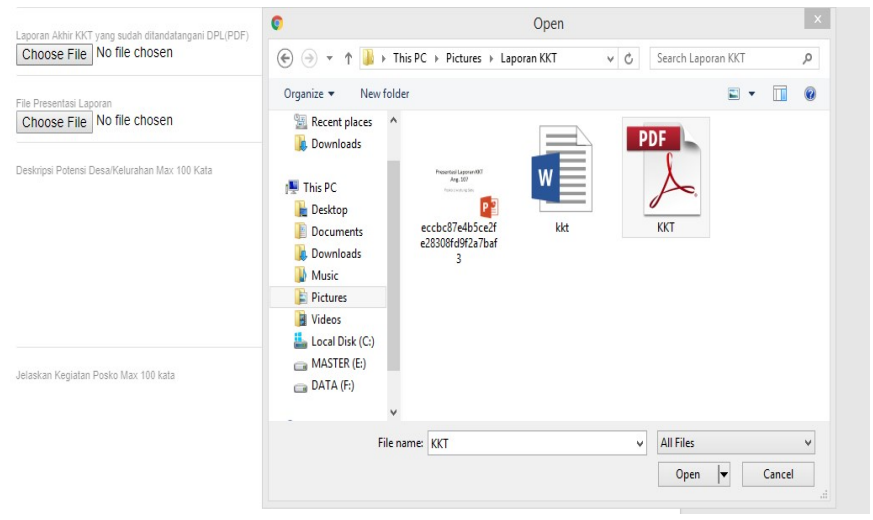

Gambar 16. Tampilan Memilih Foto

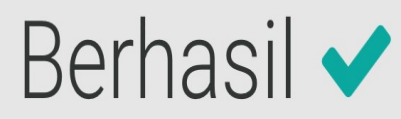

Data Anda berhasil diupload

Kembali

Gambar 17. Tampilan Notifikasi Berhasil 
10)Gambar 18 merupakan tampilan login admin, dimana admin harus mengisi user name dan password dengan benar.

11)Gambar 19 merupakan tampilan menu home admin, sebagain besar sama dengan tampilan home user, hanya beda pada fungsi dan tambahan tampilan yaitu ada fitur rekapan laporan, juga ketika memilih kecamatan akan langsung pada rekapan perkecamatan.

12)Gambar 20 merupakan tampilan hasil rekapan perkecamatan, ketika memilih kecamatan pada home maka akan menampilkan hasil rekapan, yang telah ada tanda centang adalah desa poskonya yang telah menginput laporan sedangkan yang tanda $\mathrm{x}$ belum menginput laporan.

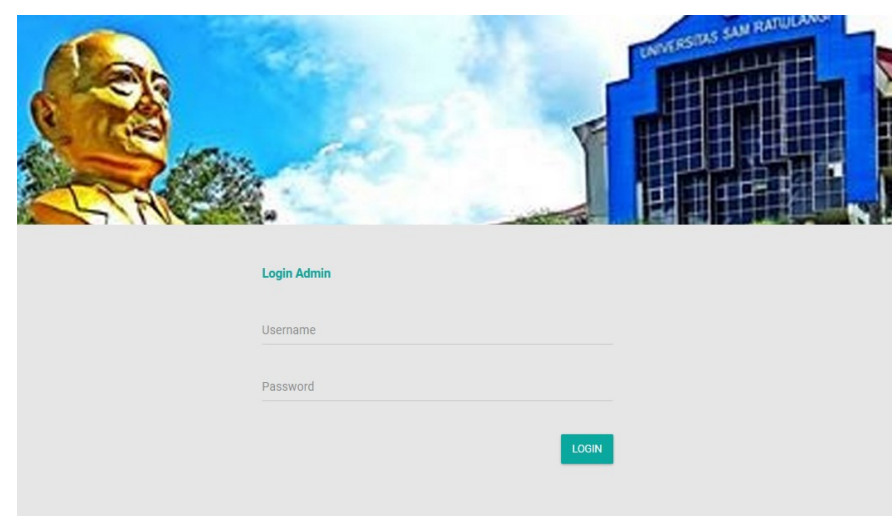

Gambar 18. Tampilan Login Admin

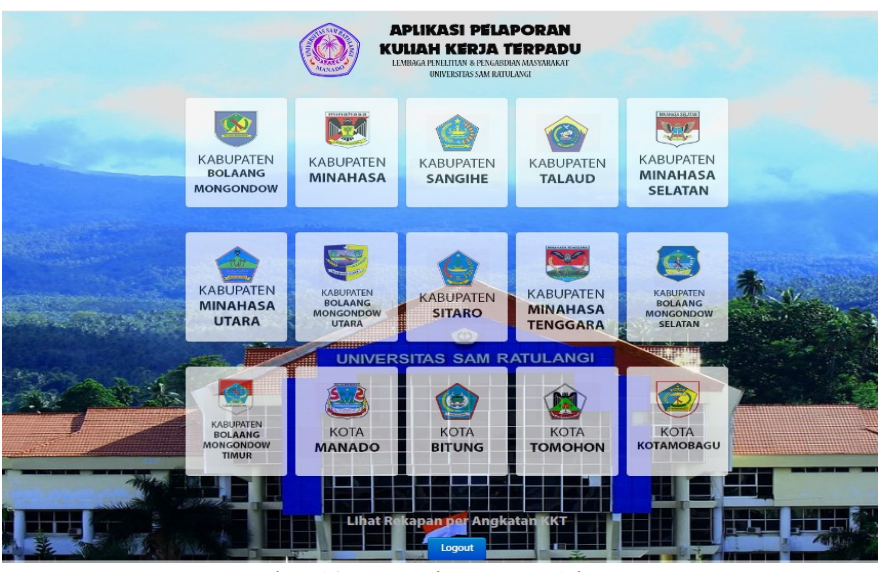

Gambar 19. Tampilan Home Admin

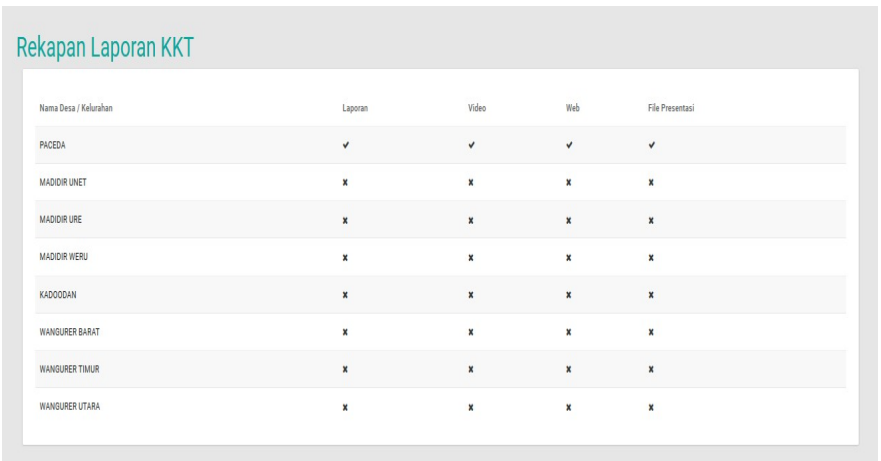

Gambar 20. Tampilan Rekapan Kecamatan
13)Gambar 21 merupakan tampilan memilih angkatan, yaitu ketika masuk pada rekapan angkatan maka akan manampilkan pilihan angkatan yang harus dipilih sesuai dengan angkatan kkt yang diikuti.

14) Gambar 22 merupakan tampilan rakapan laporan semua kabupaten pada angkatan tersebut yang telah memasukkan laporan.

15)Gambar 23 merupakan tampilan rekapan laporan yang hanya menampilkan salah satu kabupaten pada angkatan tersebut.

16)Gambar 24 dan 25 merupakan tampilan detail data yang telah diinput oleh user. Detail data dapat dilihat dengan cara mengakses nama desa yang telah tercentang atau sudah memasukkan laporan. Pada detail laporan juga dapat diunduh laporan dan foto yang telah diinput.

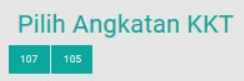

Gambar 21.Tampilan Rekapan Angkatan
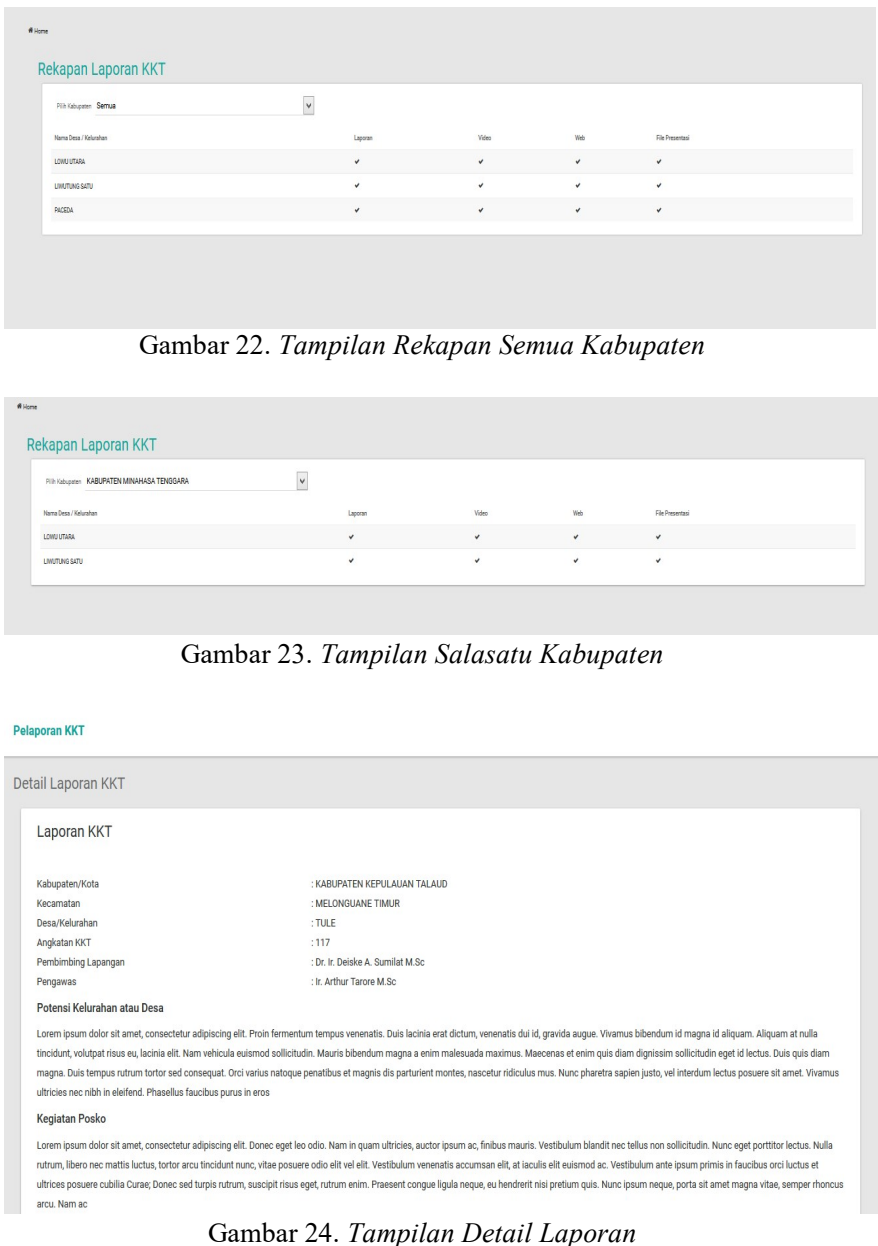


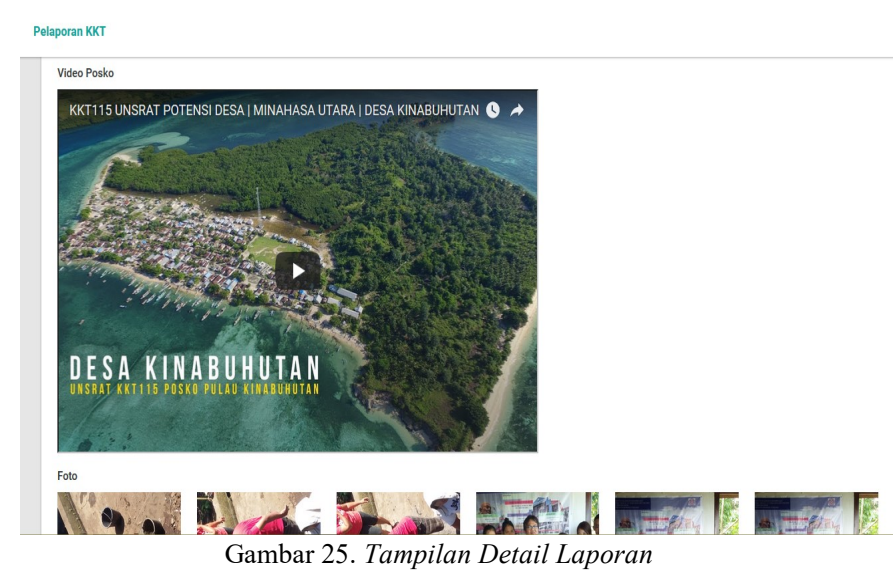

\section{KESIMPULAN DAN SARAN}

A. Kesimpulan

Berdasarkan pembahasan pada bab-bab sebelumnya maka dapat ditarik kesimpulan sebagai berikut :

1) Telah berhasil dikembangakan aplikasi pelaporan kuliah kerja terpadu Universitas Sam Ratulangi.

2) Aplikasi pelaporan kuliah kerja terpadu dikembangakan dengan metode RAD ( Rappid Application Development).

3) Aplikasi Pelaporan Kuliah Kerja Terpadu akan sangat berguna untuk memudahkan peserta juga pelaksana KKT dalam pelaporan.

\section{B. Saran}

Mengingat pentingnya pengembagan aplikasi ini maka diajukan saran sebagai berikut :

1) Penambahkan fitur tambah kota dan provinsi lokasi kkt dalam menu home.

2) Penambahan fitur edit nama, jumlah mahasiswa peserta kkt.

3) Pengembangan penerapan pada sistem android.

\section{V.KUTIPAN}

[1] Jugiyanto Hartono, (1999:11), Definisi Sistem Informasi menurut para ahli : http://www.sarjana.com.

[2] Kendall (2010), Rappid Application Development . Piyaneo: http://piyaneo.wordpress.com

[3] LPPM Pusat Pengelolaan dan Pengembangan Kuliah Kerja Nyata Terpadu- P3KKNT- LPPM Unsrat. Manado 2015

[4] Mohamad Fethurahman,2014, Pemrograman Web dan Basis Data, Jakarta.

[5] Mandag C. R, Lumenta A. S. M, Rindengan Y. D. Y, 2017, Pengembangan Sistem Informasi Kuliah Kerja Terpadu (KKT) di Universitas Sam Ratulangi. Manado : E-Journal Teknik Unsrat.

[6] Nugroho, Adi. 2006. E-commerce. Informatika Bandung. Bandung.

[7] Rektor Universitas Sam Ratulangi. Pedoman Penyelenggaraan Akademik di Universitas Sam Ratulangi, Universitas Sam Ratulangi, Manado. 2013.
[8] Roger, S. Pressman, Ph.D., 2012,2015 Rekayasa Perangkat Lunak, Yogyakarta :Andi.

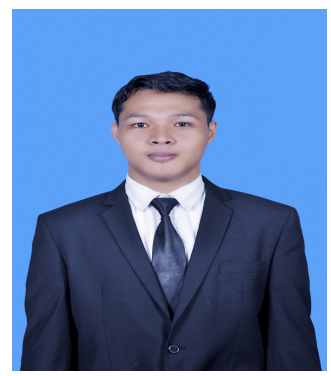

Hermawan Lalompoh lahir di Melonguane 28 Juni 1993. Anak kedua dari pasangan Amos Lalompoh dan Jorna Menaung.

Dengan latar belakang pendidikan di Taman KanakKanak Pertiwi Tule (1998-1999). Kemudian melanjutkan studi di sekolah dasar SDN Inpres 4/82 Tule (1999-2005). Kemudian melanjutkan studi ke Sekolah Menengah Pertama Negeri 3 Melonguane (2005-2008) dan selanjutnya saya menempuh studi ke Sekolah Menengah Atas Negeri 1 Lirung (2008-2011). Setelah itu, di tahun 2011 saya melanjutkan pendidikan ke salah satu perguruan tinggi yang berada di Manado yaitu Universitas Sam Ratulangi Manado, dengan mengambil Program Studi S-1 Teknik Informatika di Jurusan Elektro Fakultas Teknik. Pada Tahun 2017 , penulis membuat Skripsi demi memenuhi syarat Sarjana (S1) dengan penelitian berjudul Pengembangan Aplikasi Pelaporan Kuliah Kerja Terpadu Universitas Sam Ratulangi Manado, yang dibimbing oleh dua dosen pembimbing yaitu

Yaulie D. Y. Rindengan, ST., MSc., MM

dan Arie S. M. Lumenta, ST., MT

sehingga pada tanggal 16 Agustus 2018 penulis resmi lulus di Teknik Informatika Universitas Sam Ratulangi Manado menyandang gelar sarjana komputer dengan predikat sangat memuaskan. 